\title{
Persistence and Variation in the Distribution of Bottom-trawl Fish Assemblages over the Flemish Cap
}

\author{
D. González-Troncoso, X. Paz and X. Cardoso \\ Instituto Español de Oceanografía, P. O. Box 1552, Vigo, Spain
}

\begin{abstract}
González-Troncoso, D., X. Paz, and X. Cardoso. 2006. Persistence and Variation in the Distribution of Bottom-trawl Fish Assemblages over the Flemish Cap. J. Northw. Atl. Fish. Sci., 37: 103-117. doi:10.2960/J.v37.m550
\end{abstract}

\begin{abstract}
The aim of this study is to test the variability of the assemblages defined in the Flemish Cap area. Data from 951 bottom hauls were analysed, covering depths between 126 and $740 \mathrm{~m}$ in the years 1995-2002. The fish fauna in Flemish Cap appears distributed in a persistent structural zonation defined in three assemblages. The first three factors of a Principal Component Analysis explained the $78.4 \%$ of the variance in distribution species, and they are consistent with the results of a cluster analysis. The three characteristic assemblages show a temporal persistence, but some changes appear in this period, for instance: displacements of the assemblages limits towards shallower waters, and some changes in relative position of the dominant species in each assemblage. These changes can be related with the constant decrease of the biomass of the main demersal fish species like Atlantic cod and American plaice. The species of Genus Sebastes appear as dominant fish species in the area.
\end{abstract}

Key words: Demersal, dominance, ecosystem, Gadus morhua, Hippoglossoides platessoides, northwest Atlantic, Sebastes

\section{Introduction}

In recent years, attention has started to shift towards determining the role of species in their ecosystem and the likely impacts of fishing on them. As our knowledge on ecosystem interactions and processes increases, fisheries management is likely to move away from singlespecies approaches towards ecosystem-based strategies (Kendrick and Francis, 2002).

Fish represent the major biomass component of marine ecosystems. Interactions among fish species, and between fish and their physical environment, are important to define the structure, diversity and stability of marine ecosystems. Therefore, the study of fish assemblages is an important step in this study. However, interactions are difficult to observe in practice. The simplest way to asses potential interactions may be to identify "fish assemblages", which are defined here as groups of spatially and temporally co-occurring fish.

Numerous attempts have been made worldwide to identify fish assemblages (Bianchi, 1991, 1992; Koslow, 1993; Fujita et al., 1995; Gomes et al., 1995; Fariña et al., 1997; Mahon et al., 1998; Bergstad et al., 1999; Francis et al., 2002; Beentjes et al., 2002; Gaernet et al., 1999; Jay, 1996). A common approach involves multivariate analysis of abundance or presence-absence data from bottom trawl surveys. Some fish assemblages are stable on a time scale of decades (Musick et al., 1996).
The Flemish Cap is located in NAFO Division 3M and centred at about $47^{\circ} \mathrm{N} 45^{\circ} \mathrm{W}$ (Fig. 1). Templeman (1976) provides a background of the biology and hydrography of the Flemish Cap area. Stein's (1996) presented an overview of the oceanography of the zone.

Fish assemblages, their structure and temporal persistence have been recently under analysis in several zones of the North Atlantic (Musick et al., 1996); the Northwest Atlantic (Mahon et al., 1998; Lee and Sampson, 2000) and other intensely exploited areas: New Zealand, (Francis et al., 2002); Norwegian Sea (Bergstad et al., 1999); Portugal shelf (Gomes et al., 2001). However, these aspects have hardly been studied in Flemish Cap.

Several studies have described the biology and ecology of Flemish Cap fish species (Rodríguez-Marín et al., MS 1994; Rodríguez-Marín and De Cárdenas, MS 1997; Saborido-Rey and Junquera, 1999 a,b; Murua, MS 2000; Saborido-Rey, MS 2001; Alpoim et al., MS 2002). Most previous works concerned single species and speciesspecific spatial distributions, population dynamics or biology. However, in this study we have focused on the assemblages of fish species. A similar approach can be found in Paz and Casas (1996).

A bottom trawl survey on Flemish Cap has been performed by the European Union since 1988 (Vázquez, MS 2000; MS 2002). The results are useful to describe 


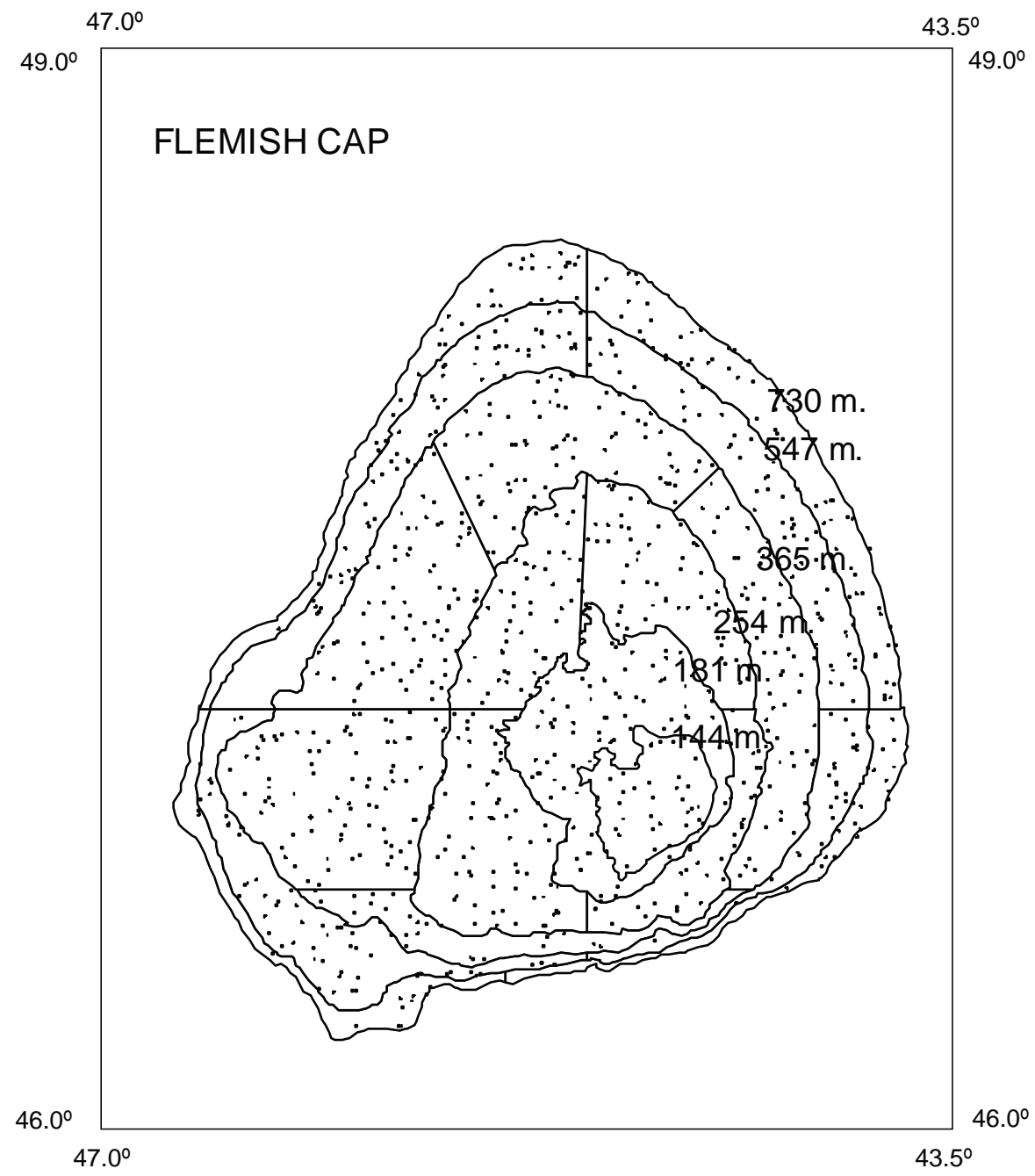

Fig. 1. Chart showing the positions of bottom trawl stations on Flemish Cap area between the years 1995 and 2002 with the approximate isobaths.

the abundance and spatial distribution of demersal and mesopelagic fish species.

The biomass and abundance of some commercial fish stocks in Flemish Cap have strongly decreased in the last years according to EU survey results (Fig. 2). The cod biomass was 103644 tons in 1989, 24062 tons in 1994 and 2270 tons in 2002. The stock has been under a fishing moratorium since 1999 , and little improvement is expected in the near future given the absence of recruitment after 1992. American plaice has also been under a fishing moratorium since 1996; its biomass was 11887 tons in 1988, 6173 tons in 1994 and 1536 tons in 2002, with a minimum of 1204 tons in 2000. Both stock biomass and spawning stock biomass are at very low levels and there is no sign of recovery due to the consistent year-to-year recruitment failure since the beginning of the 1990s. For redfish, abundance remained stable from 1996 to 2001, and increased afterwards due to the recruitment of the above average 1998-2000 yearclasses. In 2004, SSB was still well below the 1990's level, which produced a strong recruitment. The current fishery is targeting shrimp and redfish in depth less than $700 \mathrm{~m}$ and Greenland halibut in depths more than $700 \mathrm{~m}$ (Casas and González-Tronoso, 2003; NAFO, 2004; 2005).

The changes in abundance of some dominant species should have consequences on their distribution and aggregation pattern. The objective of this paper is to describe the homogeneity and heterogeneity of dominant fish fauna in Flemish Cap for the period 1995-2002 and 

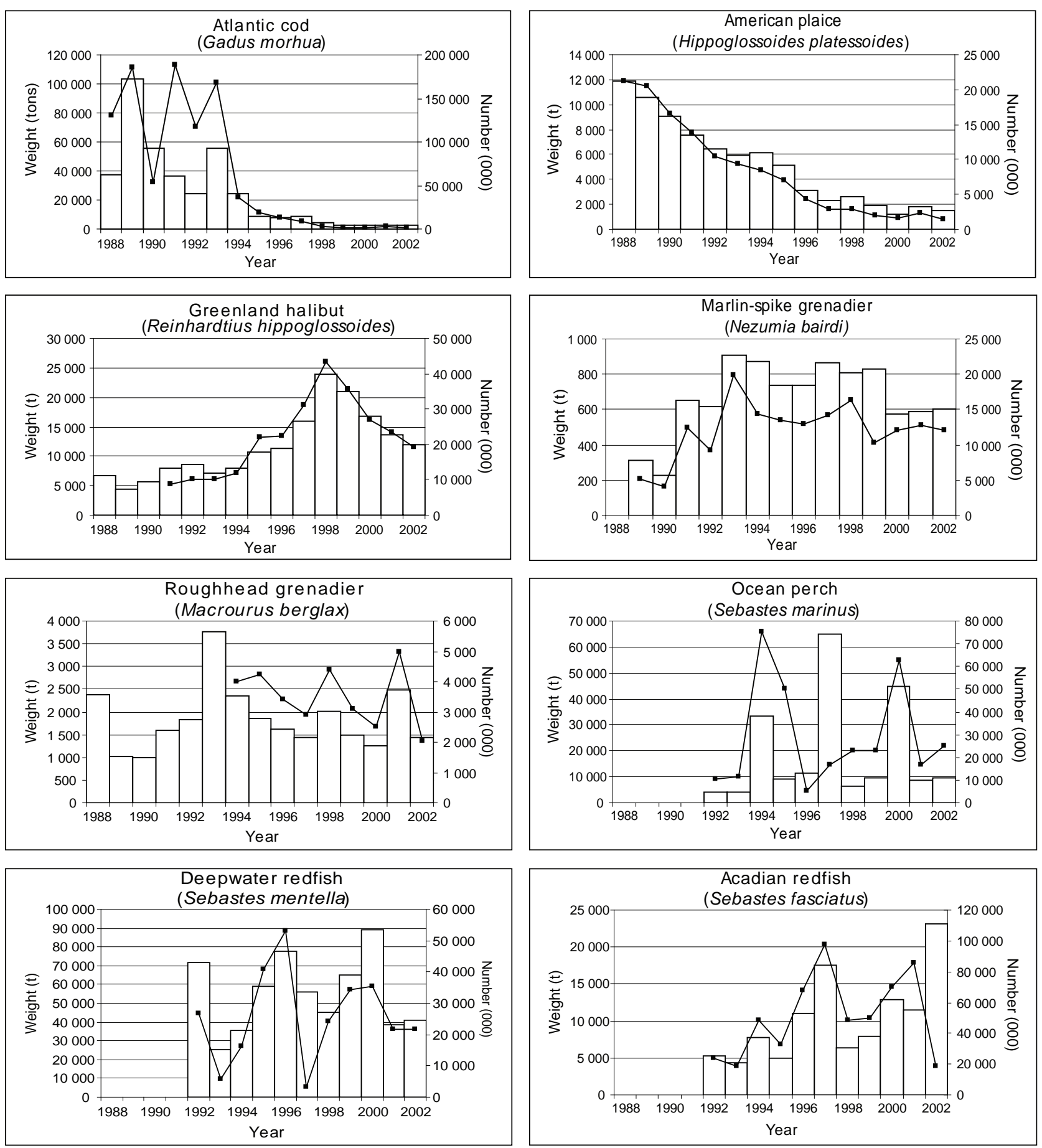

Fig. 2. Weight (bars) in metric tons and abundance (lines) in thousands of the principal captured species in Flemish Cap in years 1988-2002.

to explore the possible changes that took place in the communities as described in previous works (Paz and Casas, 1996).

We have tried to know firstly the structure and specific composition of the population in assemblages by depth. We have also tried to find out the relative importance of the considered dominant species in order to see the relation between the possible changes with fishing effects in the interspecific structures and the evolution of the abundance of each population. To do this, we have used in this paper four different analysis: Empirical 
cumulative distribution function, cluster analysis via Bray-Curtis measure, Correspondence analysis and Principal Component analysis.

In order to better understand the interaction of the different species found in Flemish Cap, we have included a table in the Appendix with a complete list of the studied species. In this table the family, the common name, the type of habitat, the maximum length, the trophic level and the depth of each species are shown. The species in this table are ordered firstly by habitat type, and secondly by trophic level (upward).

\section{Material and Methods}

The period studied in this paper is 1995-2002. The data base corresponds to the sampling results from standard groundfish research trawl survey conducted by the European Union in summer between 1988 and 2002. The survey used a stratified random sampling design, with strata based on depth boundaries of 144, 181, 254, 365,547 and $730 \mathrm{~m}(80,100,200,300$ and 400 fathoms) (Fig. 1). A description of the demersal sampling gear used can be found in Vázquez (MS 2000); it was the same throughout the study period. The survey sample unit was defined as the swept area by a Lofoten trawl towed at a constant speed of $1.8 \mathrm{~ms}-1$ ( 3.5 knots) for $30 \mathrm{~min}$.

In each survey the sets were allocated to strata according to area, with all strata containing at least two sets. Details of the survey are described by Vázquez (MS 2002). Some information about the surveys is shown in Table 1.

A species was not considered when its weight was less than 15 grams or only one specimen was found. These criteria were not applied to the mesopelagic

TABLE 1. Number of trips and hauls made during Flemish Cap EU bottom Trawl Surveys on R/V Cornide de Saavedra. NAFO Divisions 3M: 1995-2002.

\begin{tabular}{lcc}
\hline \hline Year & Valid hauls & Depth range \\
\hline & & \\
1995 & 121 & $126-721$ \\
1996 & 117 & $135-710$ \\
1997 & 117 & $133-720$ \\
1998 & 119 & $137-712$ \\
1999 & 117 & $133-718$ \\
2000 & 120 & $135-704$ \\
2001 & 120 & $132-720$ \\
2002 & 120 & $130-740$ \\
Total & 951 & $126-740$ \\
\hline
\end{tabular}

species (Serrivomer beani, Chaulodius sloani and Stomias boa) due to the small size and low frequency of appearance, because of their low catchability with the gear used.

Twenty-two demersal and three mesopelagic species were included in the analysis. They consisted of commercial and non-commercial species, but they were potentially dominant species in a given region, or potential forage for other species. The species of genus Sebastes were identified every year and three species were considered in the analysis: Sebastes marinus, S. mentella and S. fasciatus. These 25 species amounted more than $89 \%$ of the catch. All species were present at least in $8.4 \%$ of the total observed tows, except Synaphobranchus kaupi $(2.6 \%)$. All strata were sampled with sufficient intensity to assess their composition.

As a preliminary analysis to establish whether zonation was present, an application of the chi-square test (Gardiner and Haedrich, 1978) was used. This method is applied to the presence or absence of the species. To apply it, the bottom trawl available hauls were arranged in order of increasing depth, the area studied was randomly divided into seven depth regions of $100 \mathrm{~m}$ depth ranges ( $\leq 150 \mathrm{~m}, 151-250 \mathrm{~m}, 251-350 \mathrm{~m}, 351-450 \mathrm{~m}$, $451-550 \mathrm{~m}, 551-650 \mathrm{~m}$, and $\geq 651 \mathrm{~m}$ ) and the number of species that appeared for the first time in each region (upslope boundaries; they had not appeared before in any region) were recorded. This method tests the distribution across the area of upslope boundaries using the formula:

$$
\chi^{2}=\frac{Q}{K}\left(V-\frac{K^{2}}{Q}\right) \quad \text { with } Q-1 \text { degrees of freedom }
$$

where: $Q=$ numbers of regions into which the area was randomly divided,

$$
\begin{aligned}
K= & \text { total number of species, and } \\
V= & \text { sum of squares over all regions of the } \\
& \text { number of upslope boundaries. }
\end{aligned}
$$

The null hypothesis is that the locations of upslope boundaries are uniformly distributed along the gradient, and that there is no tendency towards clustering. In order to reject this null hypothesis with a significant level of $\alpha$, a two-tailed test is performed using the chi-square statistic with $Q-1$ degrees of freedom and values of $\alpha / 2$ at each tail. So, values of the index were compared with those in a chi-square table for Q-1 degrees of freedom. If the calculated value exceeded the value obtained from the table, the upslope boundaries were considered to be distributed non-randomly, i.e., they are zoned. 
The preliminary explorations were made to identify associations among the catches of the 25 selected species. Cumulative distributions of the number of the specimens caught by species were compared with the empirical cumulative distribution of the depths of the hauls. The numbers of hauls in each stratum were strictly proportional to stratum area, so that the different size of the strata can be ignored (Perry and Smith, 1994).

If there was no particular association between fish distribution and depth within the area surveyed, e. g., if the fish were randomly distributed with respect to depth, then the cumulative distribution function for each species would be almost identical to the function for depth. Conversely, when the fish were associated with a small depth range, then these functions would be very different.

These cumulative distribution functions were plotted (Fig. 3) and the potential boundaries were examined by calculating the percentage similarity between the regions involved. Percentage similarity is a commonly-used measure of faunal overlap and was calculated according to the formula of Whittaker and Fairbanks (1958):

$$
P S=100\left(1.0-0.5 \sum\left|P_{i a}-P_{i b}\right|\right)
$$

where $P_{i a}=$ the proportion assumed by species in sample, and

$$
\begin{aligned}
P_{i b}= & \text { the proportion assumed by species in } \\
& \text { sample. }
\end{aligned}
$$

Percentage similarity is an insensitive index to sample size, but it is in fact highly sensitive to the relative number of species among the regions involved (e.g., if the sample size varies excessively among strata and the species number is closely related to sample size, it will lead to a downwardly biased perception of affinities among strata (Koslow, 1993)). In the current work, the narrow depth range analysed showed small differences in the species number recorded and little relation with the sample size.

Cluster analysis was used to assess faunal change with depth and to contrast with the results based on analysis of the percentage similarity data. We used the commonest type of cluster analysis, joining analysis, in which samples were arranged into groups where each had a similar biotic composition.

To reduce the large number of sets (951) for the 1995-2002 period, the sets were grouped into class depth of $50 \mathrm{~m}$ for every two years. These class-depths or strata were labelled with the maximum depth value of the class. Therefore, for every two years (1995-96,
1997-98, 1999-2000, 2001-02) there were 13 strata named: $150,200,250, \ldots, 750$, i.e., we have a total of 52 strata.

The classification and ordination analysis were based on a matrix of similarity coefficients among strata. To calculate the similarity coefficients we used the mean numbers of specimen per strata for each species.

The data (number of specimens for each species) were previously root-root transformed $\left(x^{1 / 4}\right)$. This transformation has the effect of scaling down the scores of abundant species to avoid swamping the other data (Field et al., 1982). Moreover, the root-root transformation has the advantage that, when similarity is assessed by the Bray-Curtis measure, the similarity coefficient is invariant to a scale change (Stephenson and Burges, 1980).

We have adopted the Bray and Curtis measure of similarity because it is not affected by joint absences (Field and McFarlane, 1968) and is, therefore, sufficiently robust for marine survey data where many of the species are absent from the majority of the samples, while it gives more importance to abundant species (in comparing samples) than to rare ones.

The Bray-Curtis measure has the form:

$$
\delta_{j k}=\frac{\sum_{i=1}^{s}\left|Y_{i j}-Y_{i k}\right|}{\sum_{i=1}^{s}\left(Y_{i j}+Y_{i k}\right)}
$$

where: $Y_{i t}=$ score for the species in the sample, and

$\delta_{j k}=\begin{aligned} & \text { dissimilarity between the and the } \\ & \text { samples summed over all species. }\end{aligned}$

The dissimilarity matrix of the data was calculated in Matlab (The MathWorks, Inc., 2002).

The clustering strategy is the hierarchical weighted group-average sorting, which joins two groups of samples together at the average level of similarity between all members of one group and all members of the other. Analyses were carried out with Statistica (StatSoft, Inc., 2005).

To corroborate the results of the cluster analysis, we used two more multivariate techniques: correspondence analysis and principal components. The data used in these analyses were the same used in the cluster analysis.

Correspondence analysis is an ordination method in which each site is located at the centre of gravity of 

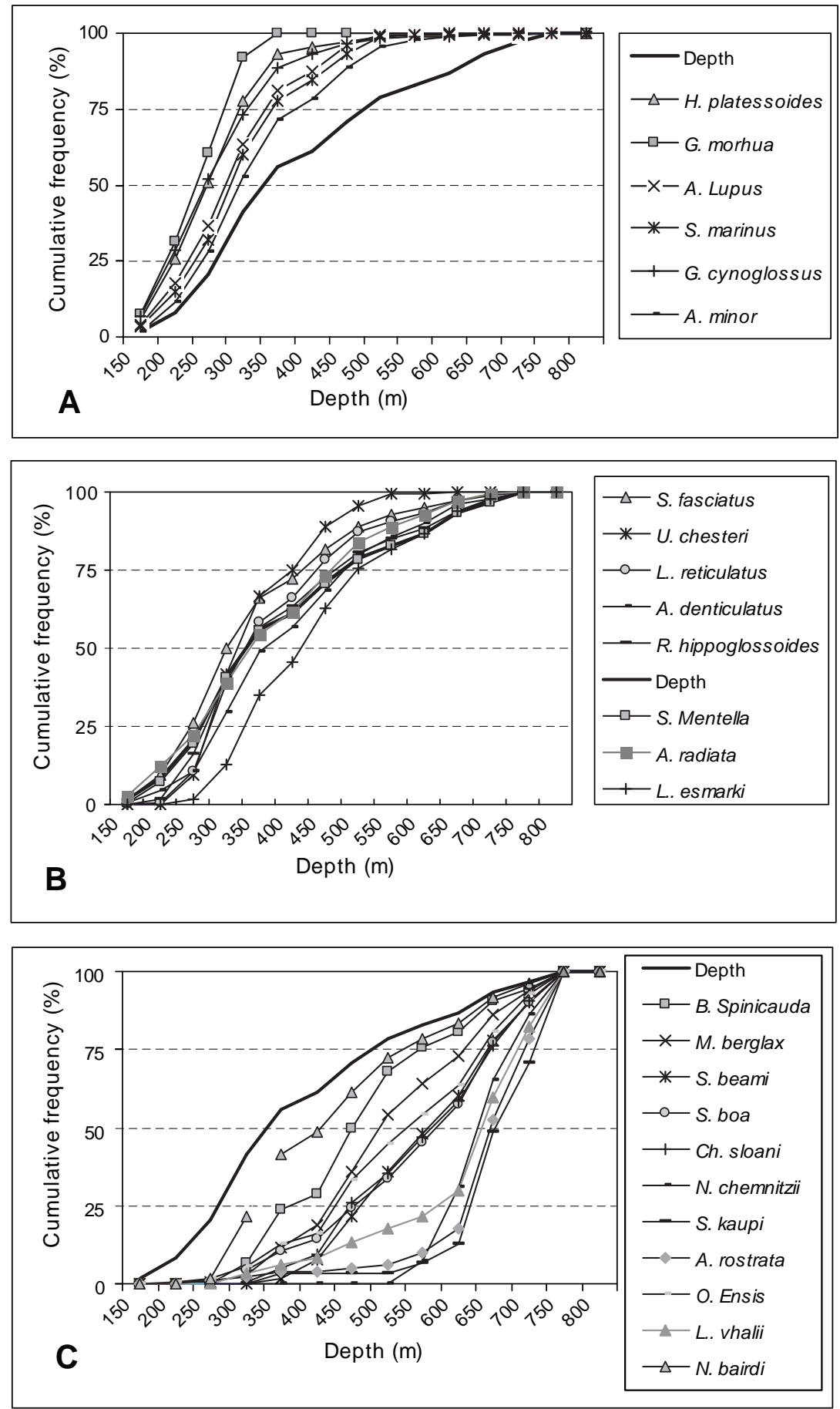

Fig. 3. Cumulative frequency distributions of depth variable and depths as weighted by number of the specimens caught for each species on Flemish Cap in summer 1995-2002. (A) Shelf group species; (B) Upper continental slope group species; (C) Middle continental slope group species

the species that occur there. This method is unaffected by double-zero, i.e., tows in which both species being compared are absent (Gauch, 1982; Jackson and Harvey, 1989; Kendrick and Francis, 2002).
Principal component analysis was also used to test the results obtained in the cluster and correspondence analysis. Species loadings of principal components were used to identify groups of species that tend to co-occur 
(i.e., assemblages). The eigenvalue associated with a Principal Component indicates the relative importance of that component. Principal components with eigenvalues $>1$ are considered to represent statistically significant assemblages (Jolliffe, 1986). VARIMAX rotation was used for the data, and performed by Statistica program. The data used were the same used for the cluster and correspondence analysis (Mahon et al., 1998).

Diversity, $H$, for the resultant depth zone was calculated using the information function (Shannon and Weaver, 1963):

$$
H=-\sum p_{i} \ln p_{i}
$$

where $p_{\mathrm{i}}=$ fraction of the total comprised by species in a region.

Regressions were performed on individual species to establish whether a correlation between size and depth existed. The size was estimated by calculating the mean weight for each species and set from the total weight of the species and the specimen number in the set.

\section{Results}

A complete list of species considered for the period studied 1995-2002 is given in Table 2. This table shows the depth range, weight and number of specimens in the total sets by species. Each species showed an unique vertical depth range. The data are for all valid hauls (951).

The chi-square test was run on all sets for the years from 1995 to 2002, grouped into regions of $100 \mathrm{~m}$ depth intervals. The value of chi-square, $\chi_{\text {upslope }}^{2}=28.48$, exceeded the 0.01 significance level for $6 \mathrm{~d}$. f. $\left(\chi^{2}=18.55\right)$. This showed that, in the period considered, the distribution was zoned between 127 and $730 \mathrm{~m}$. However, the fact that the survey sampling did not completely cover the depth range of all species made it difficult to set up the zonation with certainty, because some species have a larger depth distribution, deeper than the range sampled.

Figure 3 shows cumulative distribution functions for observed depth and depths weighted by the number of specimens caught of each species. We constructed three graphs were the species were grouped according to similarity behaviour with respect to depth.

Basically, we found three groups of species. Group A (Fig. 3a) comprised the species with cumulative occurrence percentages higher than $50 \%$ in depths less than $300 \mathrm{~m}$, except Sebastes mentella that shows an almost identical frequency to that of the depth $(40.7 \%$ at $300 \mathrm{~m}$ versus $41.3 \%$ of the depth). In group B (Fig. 3b), the species present showed no particular association between fish distribution and the depth within the area surveyed, with a random distribution with respect to the depth. Group C (Fig. 3c) is composed of species with cumulative occurrence percentage higher than $68 \%$ in depth greater than $500 \mathrm{~m}$.

Nezumia bairdi, Lycodes smarki and Bathiraja spinicauda do not appear clearly located, between the groups B and C. To assign them into a group the respective graph of the capture was drawn concerning the bottom (Fig. 4). In this figure we represent the minimum, the maximum and the quartiles (25\%, median and $75 \%)$ of the non-cero value for each year. The biggest captures in Lycodes were concentrated between 350 and $450 \mathrm{~m}$ (group B) (Fig. 4a); in the case of Nezumia and Bathiraja spinicauda the biggest captures were carried out around $500 \mathrm{~m}$ (Fig. 4b and 4c), between group B and C. We assigned them to group $\mathrm{C}$.

The potential boundaries appear to be at 300 and $500 \mathrm{~m}$ (Fig. 3). These potential boundaries were examined by calculating the percentage similarities between regions involved. PS measured across the $300 \mathrm{~m}$ level was $55.26 \%$ and across $500 \mathrm{~m}$ level was $28.34 \%$. These data thus suggest that the distribution is zoned between 127 and $730 \mathrm{~m}$.

To contrast this result, a cluster analysis was also performed. Figure 5 is the resulting dendogram showing sample affinities based on the mean root-root transformed abundance (mean number of specimens in each stratum) of the 25 species studied, using the Bray Curtis measure of similarity and group average sorting. Three main zones or clusters were distinguished at an arbitrary dissimilarity level of $35 \%$. Cluster I comprised the strata with depth lesser than $300 \mathrm{~m}$; cluster II comprised the transition depth strata between $300 \mathrm{~m}$ and $500 \mathrm{~m}$, and cluster III the depth strata greater than $500 \mathrm{~m}$. The results showed grouping of species with similar biotic character and comparable depth preferences.

Besides, we conducted two more multivariate analyses in order to confirm the results. Cluster analysis made three exclusive groups in agreement with the three groups made by the cumulative distribution functions (Fig. 6) except for the Bathyraja spinicauda, which appears in group II instead of group III.

We made a principal components analysis. We found three components with eigenvalues greater than 1, which explains more than the $78 \%$ of the total variance (Table 3). When we graphed the two first components (Fig. 7), 
TABLE 2. Vertical depth ranges and catch data for fish species taken by bottom trawls on the Flemish Cap surveys $1995-2002$ including all valid hauls. In brackets, the 1988-94 values, except for Sebastes marinus (1990-94 values), Sebastes fasciatus and Sebastes mentella (1992-94 values) ${ }^{2}$.

\begin{tabular}{|c|c|c|c|c|c|}
\hline Maine Fish Species & FAO Code & $\begin{array}{l}\text { Depth } \\
\text { Range }\end{array}$ & $\begin{array}{l}\text { Weight } \\
(\mathrm{kg})\end{array}$ & $\begin{array}{c}\text { No. of } \\
\text { Speciments }\end{array}$ & $\begin{array}{l}\text { No. of } \\
\text { Stations }\end{array}$ \\
\hline Gadus morhua & COD & $126-343 \quad(126-631)$ & $6332(48500)$ & 8008 (119 979) & $382(459)$ \\
\hline Anarhichas lupus & CAA & $126-716 \quad(130-497)$ & $4911 \quad(4950)$ & $17860(100063)$ & $706(498)$ \\
\hline Sebastes marinus & REG & $126-643 \quad(130-441)$ & $25065 \quad(6810)$ & $64611 \quad(16220)$ & $674(253)$ \\
\hline Glyptocephalus cynoglossus & WIT & $126-677 \quad(130-738)$ & $496 \quad(540)$ & $1056 \quad(1242)$ & $289(249)$ \\
\hline Sebastes fasciatus & REN & $126-740 \quad(151-660)$ & $13846 \quad(2340)$ & $92196 \quad(12675)$ & 781 (214) \\
\hline Anarhichas minor & CAS & $126-703 \quad(129-605)$ & $6053 \quad(2590)$ & $4201 \quad$ (1 752) & $600(302)$ \\
\hline Amblyraja radiata & RJR & $126-718 \quad(126-717)$ & $1430 \quad(1950)$ & $891 \quad(1071)$ & $381(385)$ \\
\hline Sebastes mentella & $R E B$ & $145-740 \quad(249-738)$ & $66958(17100)$ & $379133 \quad(65618)$ & $763(186)$ \\
\hline Hippoglossoides platessoides & PLA & $126-716 \quad(126-519)$ & $3027 \quad(6910)$ & $3840 \quad(12412)$ & $420(456)$ \\
\hline Urophycis chesteri & GPE & $213-703 \quad(280-638)$ & $190 \quad(112)$ & $3694 \quad(1295)$ & $327(168)$ \\
\hline Lycodes reticulatus & LCT & $179-716$ (155-683) & 1295 & $(5607)$ & $571 \quad(281)$ \\
\hline Bathyraja spinicauda & RJQ & $256-719 \quad(149-717)$ & $685 \quad(853)$ & (192) & 114 (118) \\
\hline Anarhichas denticulatus & $\mathrm{CAB}$ & $144-740(130-738)$ & $1786 \quad(1130)$ & (295) & $324(167)$ \\
\hline Reinhardtius hippoglossoides & GHL & $154-740 \quad(221-753)$ & $18093 \quad(5550)$ & $(6821)$ & 799 (383) \\
\hline Lycodes esmarki & $\mathrm{SP} 1^{1}$ & $218-714 \quad(242-738)$ & $239 \quad(143)$ & 1256 & $254 \quad(73)$ \\
\hline Nezumia bairdi & NZB & $201-740 \quad(249-753)$ & $780 \quad(460)$ & (8 991) & $432(290)$ \\
\hline Macrourus berglax & RHG & $227-740 \quad(249-753)$ & $1853(1440)$ & $(2656)$ & 318 (179) \\
\hline Serrivomer beani & ASB & $316-720 \quad(249-738)$ & $37 \quad(13)$ & (151) & $115 \quad(44)$ \\
\hline Stomias boa & SBB & $244-740 \quad(313-738)$ & (4) & $(151)$ & 110 \\
\hline Chauliodus sloani & $\mathrm{CDN}$ & $284-720 \quad(263-753)$ & (19) & $(67)$ & 121 \\
\hline Notacanthus chemnitzii & NNN & $501-721 \quad(424-753)$ & $(311)$ & $(363)$ & $(65)$ \\
\hline Synaphobranchus kaupi & SSK & $300-740 \quad(466-753)$ & $(445)$ & (351) & (72) \\
\hline Antimora rostrata & ANT & $201-740 \quad(524-753)$ & $(389)$ & (3 366) & (69) \\
\hline Gaidropsarus ensis & $G D E$ & $240-740 \quad(575-738)$ & $(24)$ & (99) & 130 \\
\hline Lycodes vahlii & $\mathrm{SP} 2^{1}$ & $269-721 \quad(533-738)$ & (89) & $(372)$ & $(38)$ \\
\hline
\end{tabular}

1 non-FAO codes

2 The values in brackets are from Paz and Casas, 1996
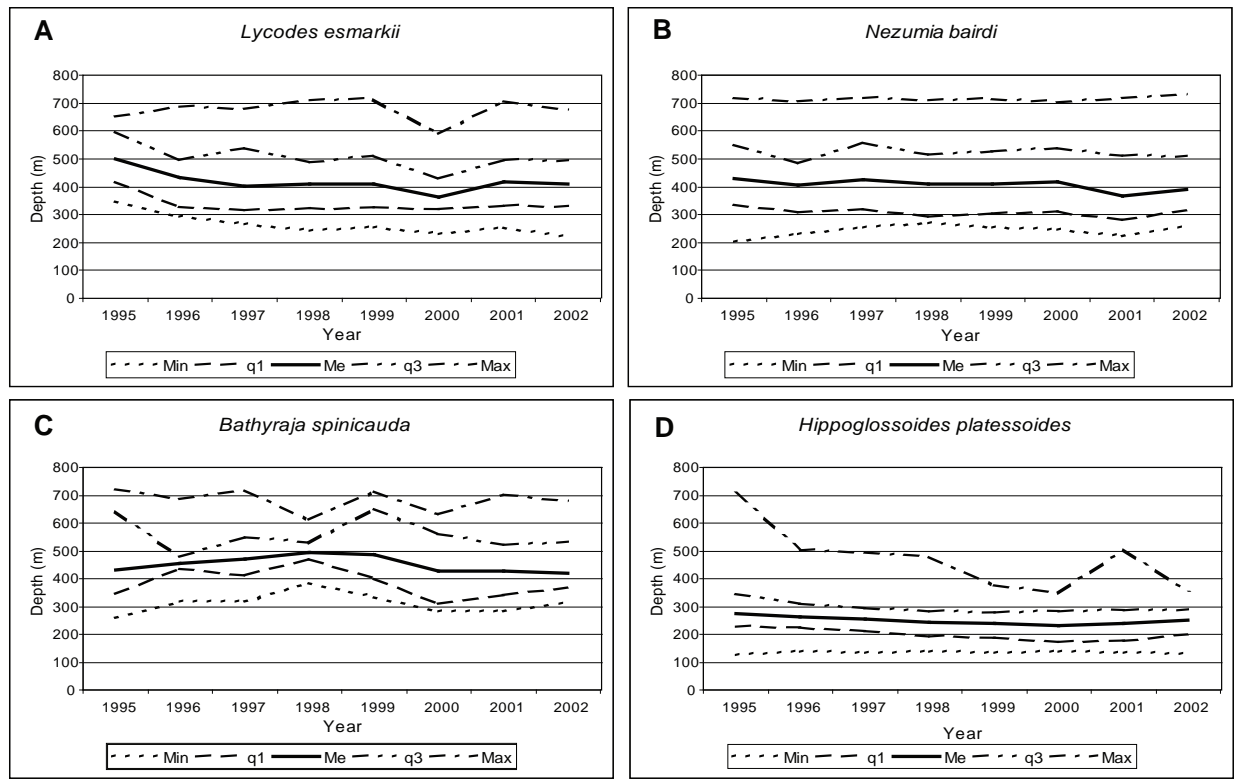

Fig. 4. Depth range of occurrence for Lycodes smarkii, Nezumia bairdi, Bathyraja spinicauda and Hippoglossoides platessoides in years 1995-2002: minimum (Min); 25\% quartile ( $q 1$ ); median (50\% quartile) (Me); $75 \%$ quartile ( $q 3)$ and maximum (Max). 


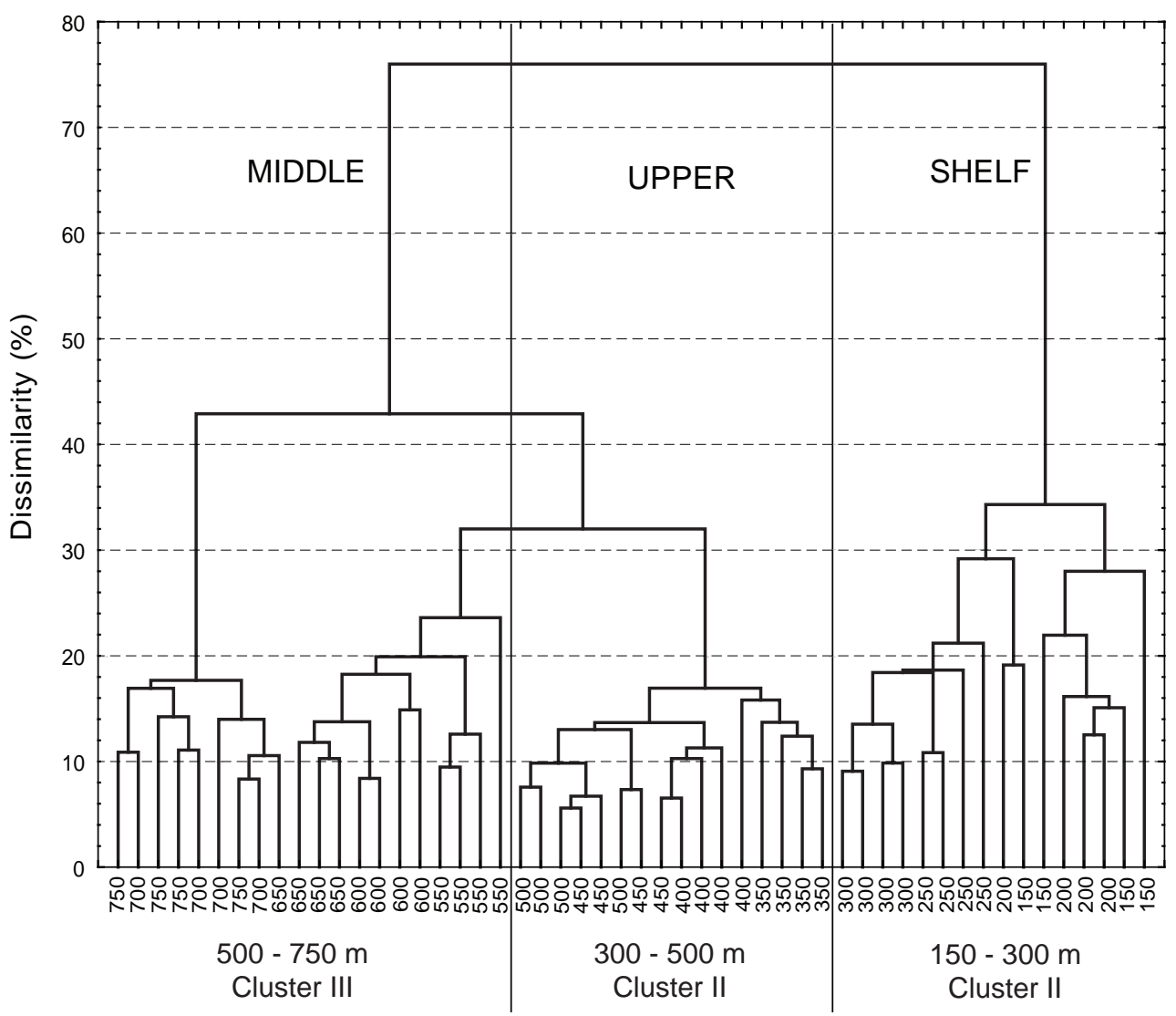

Fig. 5. Dendogram showing classification of 951 sets grouped in 13 depth class of $50 \mathrm{~m}$ by two years (1995-96, 1997-98, 1999-2000, 2001-02) based on mean abundance of fish fauna species composition by depth class. Abundance were root-root transformed before comparing stations using the Bray-Curtis measure, and the dendogram formed by group-average sorting. Three main cluster are distinguished at an arbitrary dissimilarity level of $35 \%$.

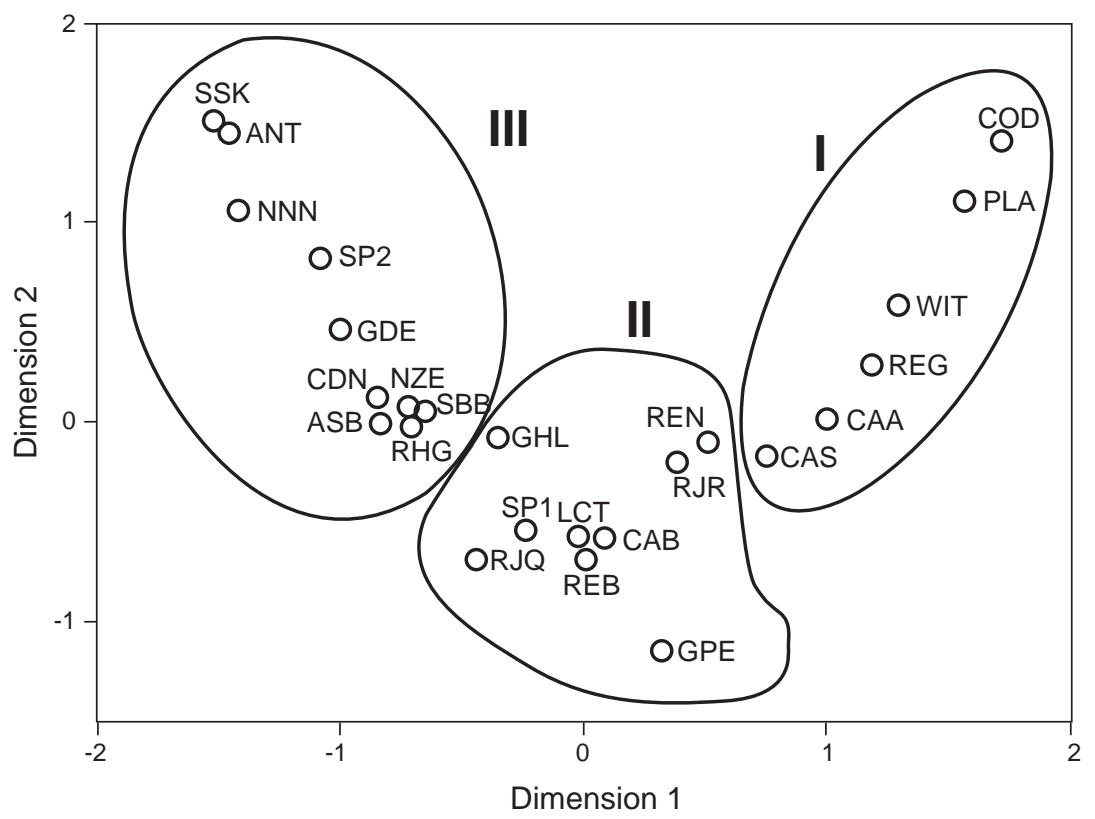

Fig. 6. Results of the Analysis of Correspondence for the 25 species used in the analysis. 
TABLE 3. Eigenvalues from the principal components analysis performed on root-root transformed data.

\begin{tabular}{lcrcc}
\hline \hline Value & Eingenvalue & $\begin{array}{c}\text { \% Total } \\
\text { variance }\end{array}$ & $\begin{array}{c}\text { Cumulative } \\
\text { Eigenvalue }\end{array}$ & $\begin{array}{c}\text { Cumulative } \\
\%\end{array}$ \\
\hline 1 & 12.5103 & 50.0410 & 12.5103 & 50.0410 \\
2 & 5.9707 & 23.8828 & 18.4810 & 73.9238 \\
3 & 1.1250 & 4.5001 & 19.6060 & 78.4240 \\
\hline
\end{tabular}

we found the same three groups of species than in the analysis below, although group I and group II superimpose with Anarhichas minor and Sebastes fasciatus.

In order to quantify the differences between these three zones: Shelf group (comprising sets shallower than $300 \mathrm{~m}$ ), Upper Continental Slope group (comprising sets between 300 and $500 \mathrm{~m}$ ) and Middle Continental Slope (comprising sets deeper than $500 \mathrm{~m}$ ). Tables 4 and 5 show, respectively, the overall community parameters and the most abundant demersal species (like percentage of total number and total biomass) in the three depth zones considered and the corresponding values for the years 1992-94 (Paz and Casas, 1996).

No species was dominant over the whole depth sampling range (Table 5). Sebastes mentella and Reinhardtius hippoglossoides were the only species present in all depth strata, standing out into upper continental slope.
Regression analysis of mean weight per individual for each species versus depth was performed (Table 6). Some species like Urophycis chesteri, Reinhardtius hippoglossoides and Sebastes mentella showed a well marked "bigger-deeper" distribution. Another species, like Macrourus berglax, Stomias boa, Sebastes marinus, Nezumia bairdi, Sebastes fasciatus and Serrivomer beani showed a less-marked "bigger-deeper" trend in distribution.

Others authors also observed this "bigger-deeper" trend in other areas for several species studied here. Polloni et al. (1979) and Snelgrove and Haedrich (1985) reported the "bigger-deeper" phenomenon, on the South of Newfoundland's continental slope, for Antimora rostrata, Synaphhobranchus kaupi and Nezumia bairdi.

\section{Discussion}

Analysis of eight years of EU trawl survey data from the Flemish Cap area identified three main fish assemblages of 25 studied species. A similar approach with the same group of species of Flemish Cap can be found in Paz and Casas (1996). In that paper, the authors established three assemblages between 300 and $600 \mathrm{~m}$ in a study of the data obtained in the EU surveys in the years 1989-94. These assemblages are consistent with the identified in this paper, although three "problematic" species (Lycodes smarki, Nezumia bairdi and Bathiraja spinicauda) were assigned to another groups in that

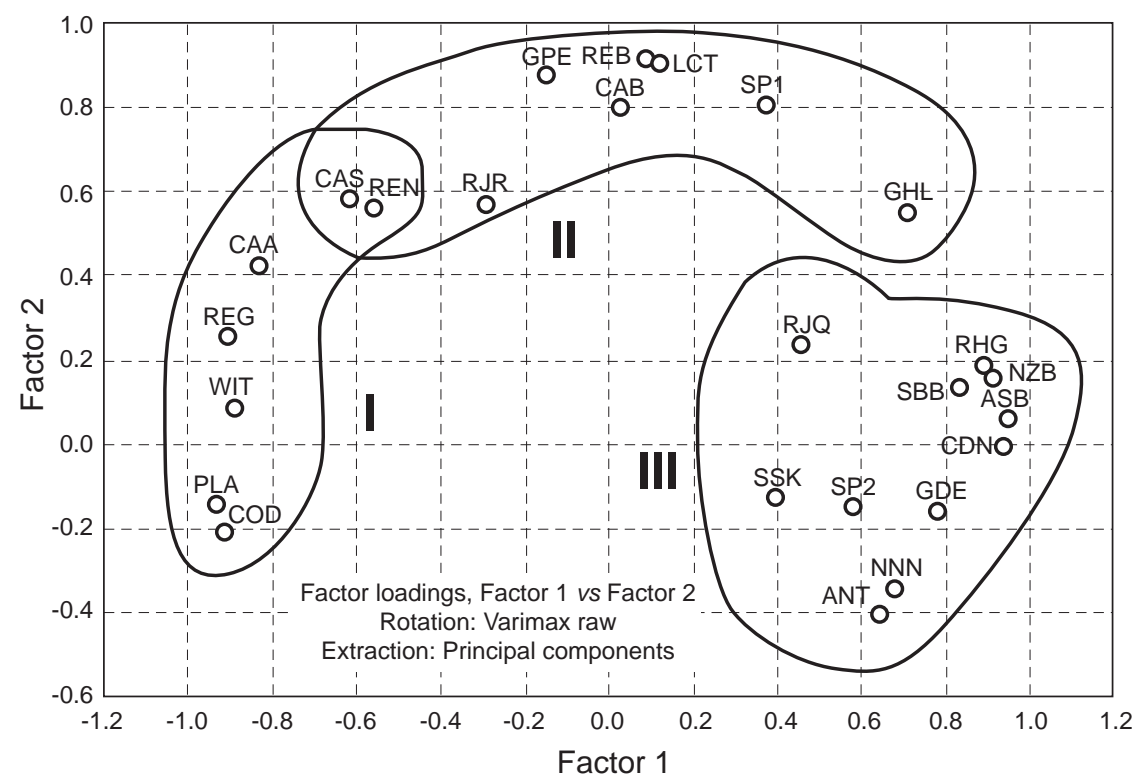

Fig.7. Results of the Principal Components Analysis for the 25 species used in the analysis. 
TABLE 4. Community parameters and catch rates for fish assemblages by depth strata on the Flemish Cap in the years 1995-2002. The 1992-94 values are in parentheses.

\begin{tabular}{lrrrrrr}
\hline \hline & \multicolumn{7}{c}{ Depth strata (m) } \\
\cline { 2 - 7 } & $127-300$ & $(126-300)$ & $301-500$ & $(301-600)$ & $501-730$ & $(601-753)$ \\
\hline Number of species & 21 & $(19)$ & 23 & $(25)$ & 21 & $(20)$ \\
Diversity, $H$ & 1.74 & $(1.4)$ & 0.98 & $(1.2)$ & 1.97 & $(2.1)$ \\
Number of specimens & 205002 & $(83611)$ & 404002 & $(79053)$ & 39290 & $(10761)$ \\
Number of stations & 468 & $(177)$ & 324 & $(123)$ & 159 & $(34)$ \\
Specimens 0.5 $\mathrm{h}^{-1}$ & 438 & $(472)$ & 1247 & $(643)$ & 1247 & $(316)$ \\
Total biomass $($ Catch kg) & 54067 & $(31400)$ & 83843 & $(23000)$ & 13401 & $(4170)$ \\
Biomass $\left(\mathrm{kg} 0.5 \mathrm{~h}^{-1}\right)$ & 116 & $(177)$ & 259 & $(187)$ & 84 & $(123)$ \\
\hline
\end{tabular}

TABLE 5. The most abundant demersal fish species at the three depth zones considered. Values are percentages of total number and of total biomass.

\begin{tabular}{|c|c|c|c|c|c|}
\hline \multicolumn{3}{|l|}{$1995-2002$} & \multicolumn{3}{|c|}{ 1992-94 } \\
\hline Species & $\begin{array}{c}\text { Number } \\
(\%)\end{array}$ & $\begin{array}{c}\text { Biomass } \\
(\%)\end{array}$ & Species & $\begin{array}{c}\text { Number } \\
(\%)\end{array}$ & $\begin{array}{c}\text { Biomass } \\
(\%)\end{array}$ \\
\hline \multicolumn{3}{|l|}{ Dominant species in depths $<300 \mathrm{~m}$} & \multicolumn{3}{|c|}{ Dominant species in depths $<300 \mathrm{~m}$} \\
\hline Sebastes mentella & 32.13 & 14.3 & Gadus morhua & 60.50 & 55.70 \\
\hline Sebastes marinus & 25.76 & 37.77 & Sebastes marinus & 14.50 & 17.20 \\
\hline Sebastes fasciatus & 22.40 & 12.37 & Sebastes mentella & 8.00 & 4.80 \\
\hline Anarhichas lupus & 5.73 & 6.33 & Sebastes fasciatus & 6.10 & 3.10 \\
\hline Reinhardtius hippoglossoides & 3.99 & 5.02 & Anarhichas lupus & 4.50 & 5.90 \\
\hline Gadus morhua & 3.84 & 11.22 & Hippoglossoides platessoides & 3.90 & 6.80 \\
\hline Total & 93.85 & 87.02 & Total & 97.50 & 93.50 \\
\hline \multicolumn{3}{|c|}{ Dominant species in depths between 301 and $500 \mathrm{~m}$} & \multicolumn{3}{|c|}{ Dominant species in depths between 301 and $600 \mathrm{~m}$} \\
\hline Sebastes mentella & 75.63 & 66.55 & Sebastes mentella & 72.00 & 63.60 \\
\hline Sebastes fasciatus & 11.34 & 8.45 & Sebastes fasciatus & 9.50 & 5.90 \\
\hline Reinhardtius hippoglossoides & 3.84 & 10.57 & Nezumia bairdi & 3.10 & 0.50 \\
\hline Sebastes marinus & 2.90 & 5.50 & Reinhardtius hippoglossoides & 2.80 & 6.30 \\
\hline Lycodes reticulatus & 2.07 & 0.82 & Lycodes reticulatus & 2.60 & 1.70 \\
\hline Anarhichas lupus & 1.50 & 1.74 & Anarhichas lupus & 2.40 & 3.30 \\
\hline Total & 97.28 & 93.64 & Total & 92.40 & 81.30 \\
\hline \multicolumn{3}{|l|}{ Dominant species in depths $>500 \mathrm{~m}$} & \multicolumn{3}{|c|}{ Dominant species in depths $>600 \mathrm{~m}$} \\
\hline Nezumia bairdi & 28.57 & 4.90 & Nezumia bairdi & 25.60 & 4.40 \\
\hline Reinhardtius hippoglossoides & 22.44 & 48.53 & Sebastes mentella & 18.40 & 24.00 \\
\hline Sebastes mentella & 19.54 & 25.12 & Antimora rostrata & 15.50 & 5.60 \\
\hline Antimora rostrata & 10.09 & 2.57 & Reinhardtius hippoglossoides & 13.80 & 33.60 \\
\hline Macrourus berglax & 7.01 & 10.22 & Macrourus berglax & 10.90 & 16.20 \\
\hline Chauliodus sloani & 2.23 & 0.22 & Chauliodus sloani & 3.00 & 0.30 \\
\hline Total & 89.89 & 91.57 & Total & 87.20 & 84.10 \\
\hline
\end{tabular}

paper, and the same happened with Anarhichas minor. Besides, it seems there is a tendency to less-deeper waters in all the species. This can be noted in the clus- ter analysis, which had established the limit between the second and the third cluster in $500 \mathrm{~m}$, instead of $600 \mathrm{~m}$. We can also note this phenomenon in Table 2. In this 
TABLE 6. Regression parameters of mean weight per individual by species versus depth where the regression was significant.

\begin{tabular}{|c|c|c|c|c|c|}
\hline \multirow[b]{2}{*}{ Species } & \multirow{2}{*}{$\begin{array}{l}\text { No. of } \\
\text { Cases }\end{array}$} & \multirow{2}{*}{$\begin{array}{l}\text { Correlation } \\
\text { coefficient }\end{array}$} & \multirow[b]{2}{*}{ Significance } & \multicolumn{2}{|c|}{$\begin{array}{c}\text { Parameters of Equation } \\
\qquad y=a x+b\end{array}$} \\
\hline & & & & $a$ & $b$ \\
\hline Anarhichas minor & 506 & -0.1782 & $<0.001$ & 2.3356 & -00202 \\
\hline Macrourus berglax & 303 & 0.2126 & $<0.001$ & 0.2065 & 0.00047 \\
\hline Anarhichas lupus & 674 & -0.2621 & $<0.001$ & 0.5245 & -0.00073 \\
\hline Stomias boa & 175 & 0.3152 & $<0.001$ & 0.0065 & 0.00002 \\
\hline Hippoglossoides platessoides & 320 & -0.3474 & $<0.001$ & 1.1355 & -0.00155 \\
\hline Sebastes marinus & 639 & 0.3564 & $<0.001$ & 0.1402 & 0.00058 \\
\hline Nezumia bairdi & 472 & 0.3800 & $<0.001$ & 0.0138 & 0.00007 \\
\hline Glyptocephalus cynoglossus & 188 & -0.3807 & $<0.001$ & 0.6990 & -0.00106 \\
\hline Sebastes fasciatus & 780 & 0.3868 & $<0.001$ & 0.0885 & 0.00015 \\
\hline Serrivomer beani & 165 & 0.4398 & $<0.001$ & -0.0284 & 0.00021 \\
\hline Reinhardtius hippoglossoides & 782 & 0.6527 & $<0.001$ & 0.1153 & 0.00113 \\
\hline Urophycis chesteri & 342 & 0.7680 & $<0.001$ & -0.0645 & 0.00035 \\
\hline Sebastes mentella & 736 & 0.8476 & $<0.001$ & -0.1533 & 0.00096 \\
\hline
\end{tabular}

table, we can see the differences over the two periods (in parentheses, the data of the period 1989-94 appears). For instance, the cod depth range in years 1989-94 was 126-631, instead of the 126-343 range in years 1995-2002. The bathymetric pattern of cod during the feeding season was related to their abundance: during periods of high abundance, densities tended to be higher at intermediate depths. However, in periods of low abundance, density was either unrelated to depth or higher in shallow waters (Swam, 1993; Chouinard and Swan, 2002). For Antimora rostrata, the depth range for 1989-94 was 524-753, and in 1995-2002, 201-740. Quite the same occurs for Gaidropsarus ensis and Lycodes valhii. On the other hand, there are species that extend their depth range, as for example Hippoglossoides platessoides or Sebastes marinus. But this effect can be caused by a punctual catch, because if we graph the preferred depths of, for example, Hippoglossoides platessoides, we can see that its depth range was decreasing in the last years (Fig. 4d).

Main changes in the relative abundance were observed in the shelf assemblage. The constant decrease in the biomass of some demersal species (Vázquez, MS 2002), traditional target species for fishing in the area, as cod and American plaice, can be the cause of changes in the composition of that assemblage. Thus, American plaice no longer appears as a dominant species, and cod loses importance in that assemblage (Table 5). The genus Sebastes, despite of its abundance decrease with regard to historical levels, is still the dominant species. This is probably because its relative presence is very high in the groundfish due to the great decrease of some of the other dominant species.

The zones $(<300 \mathrm{~m} ; 300-500 \mathrm{~m}$, and $>500 \mathrm{~m})$, established from cluster analysis, coincide with the zones defined in the calculation of the Percentage similarity index. The agreement in the results of two independent methods is an important requirement for assemblage validity. Moreover, these results coincide with Haedrich et al. (1980) for the depth range studied here compared to the deep sea South New England. These authors found distinct faunal assemblages on the shelf continental slope (40-264 m), upper continental slope $(283-650 \mathrm{~m})$ and middle continental slope (653-1 $290 \mathrm{~m})$.

Both abundance and biomass declined on the middle continental slope. In this region, however, the diversity was greater than in the other zones (Table 4). This fact has an important effect on fish community structure and eventually on the traditional fisheries (Gordon et al., 1994). The commercially important species tend to be present in low diversity communities where they are a significant proportion of the total biomass (Haedrich, 1994). In agreement with this assertion, the shelf and upper continental slope presented the smallest diversity and were the regions where the traditional commercial species exploited in the area, such as Gadus morhua and Sebastes spp., were the most important species in terms of both number and biomass. In the shelf and upper continental slope, Sebastes mentella is the most abundant species. In the upper continental slope, that species represents more than $75 \%$ of the specimen numbers and 
more than $66 \%$ of the specimen catches. In the shelf continental slope, the three species of genus Sebastes represent more than $80 \%$ of the specimen numbers and more than $64 \%$ of the specimens catches (Table 5).

The representative species of the middle continental slope were more homogeneously represented. Reinhardtius hippoglossoides, Sebastes mentella and Macrourus berglax comprise the $84 \%$ of caught biomass and make up the target fish species of the most recent fisheries in the area.

\section{Conclusions}

The fish fauna in Flemish Cap appears distributed in a persistent structural zonation defined in three assemblages. In the period 1995-2002 the bathymetric distribution of the species shows three previously defined assemblages. The specific composition remains with very few changes. The most important changes that have taken place since that first period studied are:

- Split of the limits among (between) assemblages toward less depth due to the concentration of some species in shallower waters.

- Changes in the dominant species in the shelf assemblage due to the strong decrease in the biomass of the corresponding species (Cod, American plaice).

- The species of the genus Sebastes appears as dominant species in shelf and upper continental slope groups in the last years in Flemish Cap.

\section{Acknowledgements}

Thanks to Antonio Vázquez for providing access to their trawl survey database of Flemish Cap surveys 1988-2002, and for his useful comments. Thanks to Míkel Casas for his help in the realization of this work. The authors are very grateful to the scientific staff onboard the ships. We are grateful to the editor and the anonymous referees for their comments that have helped us to improve the text.

This work was partially supported by a Caixanova grant awarded to Vigo Oceanographic Centre of the Spanish Institute of Oceanography (IEO) and also by the Spanish General Secretariat of Maritime Fishing (SGPM).

\section{References}

ALPOIM, R., A. ÁVILA DE MELO, R. BAÑON, M. CASAS, S. CERVIÑO, S. JUNQUERA, I. MARTÍN, H. MURUA,
X. PAZ, G. PÉREZ-GÁNDARAS, J. L. DEL RÍO, E. RODRÍGUEZ-MARÍN, F. SABORIDO-REY, E. J. DOS SANTOS and A. VÁSQUEZ. MS 2002. Distribution and main characteristic of fish species on Flemish Cap based on the 1988-2002 EU Surveys in July. NAFO SCR Doc. No. 72, Serial No. N4685,73 p.

BEENTJES, M. P., B. BULL, R. J. HURST and N. W. BAGLEY. 2002. Demersal fish assemblages along the continental shelf and upper slope of the east coast of the South Island, New Zealand. N.Z. J. Mar. Freshwat. Res., 36: 197-223.

BERGSTAD, O. A., O. BJELLAND and D. M. GORDON. 1999. Fish communities on the slope of the eastern Norwegian Sea. Sarsia, 84: 67-78.

BIANCHI, G. 1991. Demersal assemblages of the continental shelf slope edge between the Gulf of Tehuantepec (Mexico) and the Gulf of Papagayo (Costa Rica). Mar. Ecol. Prog. Ser., 73: 121-140.

1992. Study of the demersal assemblages of the continental shelf and upper slope off Congo and Gabon, based on the trawl surveys of the RV 'Dr. Fridtjof Nansen'. Mar. Ecol. Prog. Ser., 85: 9-23.

CASAS, J. M., and D. GONZÁLEZ TRONCOSO. 2003. Informe de la Campaña de Investigación Pesquera Flemish Cap 2003. Instituto Español de Oceanografía: 137 p.

CHOUINARD, G. A., and D. P. SWAN. 2002. Depth-dependent variation in condition and length-at-age of Atlantic $\operatorname{cod}$ (Gadus morhua) in the southern Gulf of St. Lawrence. Can J. Fish. Aquat. Sci., 59: 1 451-1 459.

FARIÑA, A. C., J. FREIRE and E. GONZÁLEZ-GURRIARÁN. 1997. Demersal fish assemblages in the Galician continental shelf and upper slope (NW Spain): Spatial structure and long-term changes. Estuar. Coast. Shelf Sci., 44: 435-454.

FIELD, J. G. and G. MCFARLANE, 1968. Numerical methods in marine ecology. I. A quantitative similarity analysis of rocky shore samples in False Bay, South Africa. Zool. Afr., 3: $119-138$.

FIELD, J. G., K. R. CLARKE and R. M. WARWICK. 1982. A practical strategy for analysing multispecies distribution patterns. Mar. Ecol. Prog. Ser., 8: 37-52.

FRANCIS, M. P., R. J. HURST, B. H. MCARDLE, N. W. BAGLEY, and O. F. OWEN. 2002. New Zealand demersal fish assemblages. Environ. Biol. Fishes, 65: 215-234.

FROESE, R. And D. PAULY. (Ed.) 2005. Fishbase. World Wide Web electronic publication. www.fishbase.org, version $(05 / 2005)$.

FUJITA, T., T. INADA and Y. ISHITO. 1995. Depth-gradient structure of the demersal fish community on the continental shelf and upper slope off Sendai Bay, Japan. Mar. Ecol. Prog. Ser., 118: 13-23.

GAERTNER, J. C., N. MAZOUNI, R. SABATIER, and B. MILLET. 1999. Spatial structure and habitat associations of Demersal assemblages in the Gulf of Lyons: a multicompartmental approach. Mar. Biol., 135: 199-208.

GARDINER, F. P. and R. L. HAEDRICH. 1978. Zonation in the deep benthic megafauna. Application of a general test. Oecologia (Berl.) 31: 311-317.

GAUCH, H. G. 1982. Multivariate analysis in community 
ecology. Cambridge, Cambridge University Press, 298 p. GOMES, M. C., R. L. HAEDRICH and M. G. VILLAGARCÍA, 1995. Spatial and temporal changes in the groundfish assemblages on the north-east Newfoundland/Labrador Shelf, north-west Atlantic, 1978-1991. Fish. Oceanogr., 4:2: 85-101.

GOMES, M. C., E. SERRAO, and M. F. BORGES. 2001. Spatial patterns of groundfish assemblages on the continental shelf of Portugal. ICES J. Mar. Sci., 58: 633-647.

GORDON, J. D. H., N. R. MERRET, and R. HAEDRICH. 1994. Environmental and biological aspects of slopedwelling fishes of the North Atlantic. In: Deep Water Fisheries of the North Atlantic Oceanic slope, A. G. Hopper (ed.). Proceedings of the NATO Advanced Research Workshop, March 1994, Kluwer, Dortdrecht, The Netherlands.

HAEDRICH, R. L., G. T. ROWE, and P. T. POLLONI. 1980. The megabenthic fauna in the deep sea south of New England, USA. Mar. Biol., 57: 165-179.

HAEDRICH, R. L. 1994. Structure over time of an exploited deep water fish assemblage. In: Deep Water Fisheries of the North Atlantic Oceanic slope, A. G. Hopper (ed.). Proceedings of the NATO Advanced Research Workshop, March 1994, Kluwer, Dortdrecht, The Netherlands.

JAY, C. V. 1996. Distribution of bottom-trwal fish assemblages over the continental shelf and upper slope of the U.S. west coast, 1977-1992. Can. J. Fish. Aquat. Sci., 53: 12031225.

JACKSON, D. A. and H. H. HARVEY. 1989. Biogeographic associations in fish assemblages: local vs regional processes. Ecology, 70: 1472-1484.

JOLLIFFE, I. T. 1986. Principal components analysis. Springer-Verlag. New York.

KENDRICK, T. H. and M. P. FRANCIS. 2002. Fish assemblages in the Hauraki Gulf, New Zealand. N.Z. J. Mar. Freshwat. Res., 36: 699-717.

KOSLOW, J. A. 1993. Community structure in North Atlantic Deep-Sea Fishes. Prog. Oceanog., 31: 321-338.

LEE, Y. W. and D. B. SAMPSON. 2000. Spatial and temporal stability of commercial groundfish assemblages off Oregon and Washington as inferred from Oregon trawl logbooks. Can. J. Fish. Aquat. Sci., 57(12): 2443-2454.

LEIM, A. H. and W. B. SCOTT. 1966. Fishes of the Atlantic coast of Canada. Bull. Fish. Res. Board Can., 155: 485 pp.

MAHON, R., S. K. BROWN, K. C. T. ZWANENBURG, D. B. ATKINSON, K. R. BUJA, L. CLAFFIN, G. D. HOWELL, M. E. MONACO, R. N. O'BOYLE and M. SINCLAIR. 1998. Assemblages and biogeography of demersal fishes of the east coast of North America. Can. J. Fish. Aquat. Sci., 55: 1704-1738.

MURUA, H. MS 2000. A review on roughhead grenadier (Macrourus berglax) biology and population structure on Flemish Cap (NAFO Division 3M), 1991-1999. NAFO SCR Doc., No. 30, Serial No. N4259, 19 p.

MUSICK, J. A., J. C. DESFOSSE, S. WILK, D. MCMILLAN, and E. GROGAN. 1996. Historical comparison of the structure of demersal fish communities near a deep-sea disposal site in the Western North Atlantic. J. Marine Env.
Engg., 3: 149-171.

NAFO. 2004. Scientific Council Reports. Northwest Atlantic Fisheries Organization. Dartmouth, Canada.

2005. Scientific Council Reports. Northwest Atlantic Fisheries Organization. Dartmouth, Canada.

PAZ, J. and J. M. CASAS. 1996. Zonation and associations of dominant fish fauna on Flemish Cap. NAFO Sci. Coun. Studies, 25: 67-75.

PERRY, R. I. and S. J. SMITH. 1994. Identifying habitat associations of marine fishes using survey data: an application to the Northwest Atlantic. Can. J. Fish. Aquat. Sci., 51: 589-602.

POLLONI, P. T., R. L. HAEDRICH, G. T. ROWE and C. H. CLIFFORD. 1979. The size-depth relationship in deepocean animals. Int. Revue. Ges. Hydrobiol., 64: 39-46.

RODRÍGUEZ-MARÍN, E., A. PUNZÓN, J. PAZ and I. OLASO. MS 1994. Feeding of most abundant fish species in Flemish Cap in summer 1993. NAFO SCR Doc., No. 35, Serial No. N2403, 33 p.

RODRÍGUEZ-MARÍN, E. and E. DE CARDENAS. MS 1997. Feeding of Greenland halibut (Reinhardtius hippoglossoides) in 3LMNO NAFO Regulatory Area Divisions (Northwest Atlantic), 1991-94. NAFO SCR Doc., No. 37, Serial No. N2869, $10 \mathrm{p}$.

SABORIDO-REY, F. MS 2001. Age and growth of redfish (Sebastes marinus, S. mentella and S. fasciatus) in Flemish Cap (Northwest Atlantic). NAFO SCR Doc., No. 109, Serial No. N4497, 19 p.

SABORIDO-REY, F. and S. JUNQUERA. 1999a. Spawning biomass variation in Atlantic cod (Gadus morhua) in Flemish Cap in relation to changes in growth and maturation. J. Northw. Atl. Fish. Sci., 25: 83-90.

MS 1999b. Sexual maturity and spawning biomass of the cod stock on Flemish Cap (Division 3M). NAFO SCR Doc., No. 29, Serial No. N4085, 11 p.

SHANON, C. E. and W. WEAVER. 1963. The mathematical theory of communication. Univ. of Illinois Press, Urbana.

SNELGROVE, P. V. R. and R. L. HAEDRICH. 1985. Structure of the deep demersal fish fauna of Newfoundland. Mar. Ecol. Prog. Ser., 27: 99-107.

STATSOFT, INC., 2005. Statistica version 7.1. Oklahoma, USA. www.statsoft.com

STEIN, M. 1996. Flemish Cap - A review on research activities with focus on oceanographic conditions. NAFO Sci. Coun. Studies, 25: 1-24.

STEPHENSON, W. T. and D. BURGES. 1980. Skewness of data in the analysis of species-in-sites-in-times. Proc. $R$. Soc. Queensl., 91: 37-52.

SWAN, D. P. 1993. Age and density-dependent bathymetric pattern of Atlantic cod (Gadus morhua) in the southern Gulf of St. Lawrence. Can J. Fish. Aquat. Sci., 50: 12551264.

TEMPLEMAN, W. 1976. Biological and oceanographic background of Flemish Cap as an area for research on the reasons for year-class success and failure in cod and redfish. ICNAF Res. Bull., 12: 91-117.

THE MATHWORKS, INC. 2002. MATLAB version 6.1. Massachusetts, USA. www.mathworks.com

VÁZQUEZ, A. MS 2000. Results from the bottom trawl sur- 
vey on Flemish Cap of July 1999. NAFO SCR Doc., No. 9, Serial No. N4228, 50 p.

MS2002. Results form bottom trawl survey onFlemish CapofJuly2001.NAFOSCRDoc.,No.12,SerialNo.N4613:
$43 \mathrm{p}$.

WHITTAKER, R. H. and C. W. FAIRBANKS, 1958. A study of plankton copecod communities in the Columbia Basin, Southeastern Washington. Ecology, 39: 46-59.

APPENDIX TABLE 1. Some characteristics of the described species.

\begin{tabular}{|c|c|c|c|c|c|c|}
\hline Name & Family & Common name & Habitat type & $L_{\max }$ & $\begin{array}{c}\text { Trophic } \\
\text { Level }\end{array}$ & Depth \\
\hline Lycodes esmarkii & Zoarcidae & Greater eelpout & Bathydemersal & 75 & 3.40 & $251-500$ \\
\hline Lycodes vahlii & Zoarcidae & Vahl's eelpout & Bathydemersal & 52 & 3.44 & $65-540$ \\
\hline Lycodes reticulatus & Zoarcidae & Artic eelpout & Bathydemersal & 36 & 3.49 & $100-380$ \\
\hline Bathyraja spinicauda & Rajidae & Spinetail ray & Bathydemersal & 170 & 3.50 & $140-800$ \\
\hline Synaphobranchus kaupi & Synaphobranchidae & Kaup's arrowtooth eel & Bathydemersal & 100 & 4.09 & $236-3200$ \\
\hline Chauliodus sloani & Stomiidae & Sloane's viperfish & Bathypelagic & 35 & & $1-1800$ \\
\hline Serrivomer beani & Serrivomeridae & Bean's sawtoothed eel & Bathypelagic & 78 & & $10-4550$ \\
\hline Stomias boa & Stomiidae & Scaly dragonfish & Bathypelagic & 32.5 & & $200-1500$ \\
\hline Antimora rostrata & Moridae & Blue antimora & Bathypelagic & 92 & 3.58 & $350-3000$ \\
\hline Sebastes mentella & Sebastidae & Deepwater redfish & Bathypelagic & 55 & 3.65 & $300-1000$ \\
\hline Urophycis chesteri & Phycidae & Longfin hake & Benthopelagic & 40 & 3.17 & $90-1400$ \\
\hline Gaidropsarus ensis & Lotidae & Threadfin rockling & Benthopelagic & 40 & 3.38 & \\
\hline Notacanthus chemnitzii & Notacanthidae & Spiny eel & Benthopelagic & 120 & 3.50 & $125-2500$ \\
\hline Nezumia bairdi & Macrouridae & Marlin-spike grenadier & Benthopelagic & 40 & 3.57 & $16-700$ \\
\hline Anarhichas denticulatus & Anarhichadidae & Northern wolffish & Benthopelagic & 180 & 3.75 & $60-900$ \\
\hline Gadus morhua & Gadidae & Atlantic cod & Benthopelagic & 200 & 4.42 & $1-600$ \\
\hline Macrourus berglax & Macrouridae & Roughhead grenadier & Benthopelagic & 110 & 4.48 & $100-1000$ \\
\hline Reinhardtius hippoglossoides & Pleuronectidae & Greenland halibut & Benthopelagic & 120 & 4.48 & $1-2000$ \\
\hline Sebastes fasciatus & Sebastidae & Acadian redfish & Demersal & 30 & & $70-500$ \\
\hline Glyptocephalus cynoglossus & Pleuronectidae & Witch flounder & Demersal & 74 & 3.14 & $45-1460$ \\
\hline Anarhichas lupus & Anarhichadidae & Wolffish & Demersal & 150 & 3.24 & $1-500$ \\
\hline Anarhichas minor & Anarhichadidae & Spotted wolffish & Demersal & 180 & 3.45 & $25-600$ \\
\hline Hippoglossoides platessoides & Pleuronectidae & American plaice & Demersal & 82 & 3.65 & $10-400$ \\
\hline Amblyraja radiata & Rajidae & Thorny skate & Demersal & 100 & 4.02 & $20-1000$ \\
\hline Sebastes marinus & Sebastidae & Ocean perch & Pelagic & 100 & 4.04 & $100-1000$ \\
\hline
\end{tabular}

Sources: Froese and Pauli, 2005 (Fishbase); Leim and Scott, 1966 
